\title{
Farlige forbindelser? \\ En refleksjon over forholdet mellom teori, praksis og moralsk ansvarlighet i okonomifaget
}

\section{Dagfinn Dohl Dybvig}

Finanskrisen har satt fornyet fokus på den praktiske betydningen av samfunnsøkonomifaget. I det følgende vil jeg diskutere fagets problematiske posisjon i overgangen mellom teori og praksis. Dette danner utgangspunkt for min påstand om at økonomene boerer et moralsk ansvar for hvordan faget direkte og indirekte legger premisser for økonomisk politikk og dermed også for den økonomiske utviklingen i samfunnet, finanskrisen inkludert. Jeg vil argumentere for at dette påkaller en etisk og epistemologisk bevisstgjøring av samfunnsøkonomiprofesjonen, og jeg antyder noen forslag til hvordan dette kan angripes.

Nøkkelord: samfunnsøkonomi, økonomisk politikk, finanskrise, yrkesetikk, talehandlinger

\section{Innledning}

«Of all economic bubbles that have been pricked, few have burst more spectacularly than the reputation of economics itself», skriver The Economist på lederplass i juli 2009. Dette fenomenet reiser for meg et spørsmål om økonomenes og økonomifagets rolle i samfunnet, både i sin alminnelighet og når det gjelder finanskrisen. Siden jeg selv ikke er økonom, men filosof og vitenskapsteoretiker, er noen ord om denne artikkelens forutsetninger og siktemål på sin plass. Først og fremst vil jeg presisere at jeg ikke er ute etter å kritisere den samfunnsøkonomiske teori per se. Dette får andre som har mer intim kjennskap til faget, eventuelt ta seg av. Det jeg ønsker å diskutere, er snarere forholdet mellom teori og praksis - eller rettere sagt: Hvordan samfunnsøkonomiprofesjonen forvalter dette forholdet. I den grad jeg 
retter noen kritikk mot samfunnsøkonomiprofesjonen, er det derfor ikke en teoretisk, men en metateoretisk kritikk; en kritikk som har å gjøre med samfunnsøkonomenes omgang med sin egen teori, og da spesielt i møte med offentligheten.

Nærmere bestemt vil en slik metateoretisk kritikk befinne seg i spenningsfeltet mellom etikk og epistemologi, for kjernen i problemstillingen er nettopp i hvor stor grad en profesjon har et etisk ansvar for å reflektere over sitt eget kunnskapsfelts forhold til den samfunnsmessige praksis. Det etiske perspektivet som ligger til grunn for denne artikkelen, er følgelig at vi alle som fagfolk har et moralsk ansvar for å klargjøre forutsetningene for våre uttalelser og intervensjoner i offentligheten. ${ }^{1}$ Her inkluderes også forutsetningene for våre beslutninger om ikke å uttale oss eller intervenere. Dette kan sees som et krav til ansvarlighet og transparens i måten man forvalter en posisjon og en kunnskap på; innbefattet, som det heter innenfor finans, et krav til «disclosure». Det vil si et krav, som jeg her anvender på metaforisk vis, om at man ikke holder tilbake informasjon om egne forutsetninger som kan være av viktighet for saken. Denne artikkelen hviler derfor på følgende resonnement:

1 Samfunnsøkonomi er et fag som opererer i skjæringspunktet mellom teori og praksis, noe finanskrisen illustrerer.

2 Alle fag som opererer i skjæringspunktet mellom teori og praksis, burde tematisere dette faktum på en systematisk måte, dvs. som en del av sin egen faglige virksomhet, hvilket også innebærer å formalisere og institusjonalisere refleksjonen som en del av utdannelsen av nye fagfolk.

3 Ergo: Samfunnsøkonomene burde, som en integrert del av det å være samfunnsøkonom, tematisere sin egen opptreden i spenningsfeltet mellom vitenskapelige og ideologiske arenaer, noe som også burde formaliseres og institusjonaliseres i utdanningen av nye samfunnsøkonomer.

Det første man da kunne spørre om er: Er det slik? Tar samfunnsøkonomene sin egen rolle i skjæringspunktet mellom teori og praksis opp til systematisk diskusjon, og avspeiles dette metaperspektivet i fagutdanningen på en formalisert og institusjonalisert måte? Et sted hvor dette spørsmålet har vært reist her i Norge, er tidsskriftet RØST, organet for det som kaller seg Radikalt økonominettverk. I et temanummer om økonomisk teori og politisk praksis i 2005 var den entydige konklusjonen at refleksjon over forholdet mellom teori og praksis er en lite behandlet problemstilling innenfor både samfunnsøkonomiutdannelsen og samfunnsøkonomiprofesjonen som sådan. ${ }^{2}$ I etterpåklokskapens lys er det derfor interessant å merke seg hvordan det innledes i dette nummeret av RØST: 
[...] økonomer [nyter] stor respekt og gir viktige innspill i samfunnsdebatten. Likevel er det liten diskusjon om økonomenes rolle som kunnskapsleverandører, og hvilke premisser som ligger til grunn for økonomenes faglige kunnskap. Vi etterlyser en bredere debatt om økonomene og økonomifaget. Når en akademisk disiplin nyter så stor innflytelse, er det ikke da på sin plass med en større bevissthet om økonomifagets rolle og forutsetninger, særlig blant økonomene selv? (Berg et al. 2005: 1)

Dette var et betimelig innspill allerede i 2005, men jeg har inntrykk av at det den gang - da det tilsynelatende gikk bra med økonomien - stort sett falt for døve ører, både innenfor og utenfor økonomenes rekker. I dag skriver vi imidlertid 2009, og med finanskrisen i full sving er det nok grunn til å tro at klimaet har bedret seg for en prinsippdiskusjon om den økonomiske teoriens forhold til samfunnsmessig praksis, og hvilke krav dette reiser til ryddighet når fagøkonomer er med, både direkte og indirekte, på å forme opinionen og den økonomiske politikken.

For å spissformulere og gjøre det klart hvor jeg står: Mitt grunnsyn er at det for fagøkonomene burde ligge en etisk dimensjon i selve det å avklare, på en systematisk og kontinuerlig basis, relasjonen mellom økonomisk teori og økonomisk praksis. Ikke minst burde de reflektere over at publikum bør ha en reell mulighet (som bare fagfolkene kan gi dem) til å vurdere hvorvidt de økonomiske ideene de konfronteres med i offentligheten, har en rent vitenskapelig karakter, og hvorvidt de er innblandet en viss mengde ideologi. Ideologi blir i denne forstand ikke i seg selv å regne som problematisk; det problematiske er et uklart skille mellom ideologi og fagkunnskap - og til syvende og sist kan jeg ikke se at noen har et større ansvar for å opprettholde et klart skille mellom ideologi og fagkunnskap enn fagfolkene selv.

Med andre ord: Der samfunnsøkonomene i kraft av sin privilegerte posisjon og kunnskap burde ha fungert som garantister for et transparent skille mellom økonomisk teori og ideologi i offentligheten, har profesjonen snarere (gjennom manglende intervensjon) gitt sin implisitte velsignelse til utviskningen av dette skillet, med den konsekvens at ulike økonomiske og politiske interessegrupper har fått anledning til å gi sine egne agendaer et urettmessig skinn av vitenskapelig kredibilitet.

I mine øyne er det nettopp dette som til syvende og sist ligger bak fenomenet The Economist beskriver med ordene «of all economic bubbles that have been pricked, few have burst more spectacularly than the reputation of economics itself» (The Economist 2009: 11) - nemlig at finanskrisen har fått lov til vokse frem i ly av en generell forvirring av ideologi og vitenskap, og at faget og fagfolkenes gode navn og rykte nå står i fare fordi fagfolkene i skuffende liten grad brukte sin unike posisjon til å bidra til å rydde opp i denne forvirringen $f ø r$ krisen endelig ble et faktum.

I den grad jeg våger å komme med noen forslag til hvordan å forebygge lignende situasjoner i fremtiden, så vil jeg antyde to typer tiltak: 
1 Systematisk refleksjon over forholdet mellom teori og praksis bør gjøres til en integrert del av den samfunnsøkonomiske utdanningen.

2 Profesjonen bør søke å artikulere et profesjonsetisk grunnsyn som bidrar til å sette fokus på de farlige forbindelsene som kan oppstå mellom ulike typer og nivåer av økonomisk diskurs hvis ikke høye standarder for transparens overholdes.

På meg virker ikke dette som spesielt strenge eller urimelige krav. Langt på vei kan man si at denne typen krav, det vil si krav til refleksjon over egen virksomhet (i mange forskjellige former), er en selvfølge for de fleste fag som (1) har en privilegert og kritisk samfunnsmessig funksjon, og (2) krever utdannelse på universitets- eller høyskolenivå. Man kunne for eksempel nevne leger, psykologer, sykepleiere, lærere, jurister/advokater, politifolk, offiserer og journalister - i tillegg til den faggruppen som jeg selv underviser for, nemlig bedriftsøkonomer, som i senere tid har opplevd et stadig økende fokus på etikk. På dette grunnlag kunne man, som jeg gjør i denne artikkelen, spørre hvorfor nettopp samfunnsøkonomi, som kanskje mer enn noen annen vitenskap i dag utgjør et «statsbærende» fag, med en hærskare praktiske utøvere innenfor politikk, forvaltning og næringsliv, skulle være unntatt fra denne typen hensyn.

Dermed håper jeg det fremgår klart at dette er en etisk og epistemologisk kritikk basert på alminnelige krav til saklighet og åpenhet - en metakritikk - snarere enn et forsøk på å avgjøre om den samfunnsøkonomiske teorien som sådan er rett eller gal, noe jeg åpenbart er lite kvalifisert til å uttale meg om. Og i den grad jeg gir samfunnsøkonomene noen skyld for finanskrisen, så er det fordi jeg mener at de i kraft av sin kunnskap og posisjon kunne ha gjort mer for å rydde av veien noe av den faglige og ideologiske forvirringen som gjorde finanskrisens eksesser mulige. Dette er den generelle bakgrunnen for min intervensjon. Den umiddelbare foranledningen er imidlertid en gjestekommentar i Dagens Næringsliv som illustrerer problematikken jeg peker på, og som jeg nå vender meg mot.

\section{Homo oeconomicus - Quo vadis?}

I en gjestekommentar i Dagens Næringsliv den 26. juni 2009 fremsetter Harald Magnus Andreassen, sjefsøkonom i First Securities, et resonnement som ved første øyekast fortoner seg så paradoksalt i sine implikasjoner at det påkaller filosofisk ettertanke, både i etisk og i epistemologisk forstand. Resonnementet - under spissformuleringen «Hvem skal passe på oss nå, da?» - går i korthet ut på følgende: (1) Finanskrisen skyldes i bunn og grunn feil begått av fire grupper samfunnsaktører: långivere, låntagere, ratingbyråer og politikere. (2) Av disse er det i all vesentlighet politikerne som må ta 
skylden for finanskrisen, for det er deres ansvar å passe på de øvrige aktørene. Andreassen skriver: «[...] en god politikk må ta høyde for at det gjøres feil i finanssektoren.» Etter å ha etablert dette grunnleggende ansvarsforholdet går han videre til å hevde at det i hovedsak ble begått to typer "politikerfeil». Det er verdt å sitere beskrivelsen av disse (mine kursiveringer):

Den første [feilen] var at myndighetene i mange land i realiteten la til grunn at eierne av de enkelte banker og finansinstitusjoner forsto og var $i$ stand til å ivareta sitt eget beste [og derfor gikk inn for omfattende dereguleringer av bank og finans i årene forut for krisen]. (Andreassen 2009)

Og:

Den andre feilen var at myndighetene i det som var igjen av reguleringer la mer vekt på soliditeten i den enkelte bank enn på stabiliteten i hele det finansielle systemet, makrostabiliteten. (Andreassen 2009)

Noe av det paradoksale ved denne analysen er at de finansielle dereguleringene ikke bare fant sted etter omfattende påtrykk fra finansbransjen, men også etter påtrykk fra fagøkonomer, inkludert (som Andreassen påpeker) den tidligere sentralbanksjef Alan Greenspan (jf. Krugman 2009a). Dermed ser det ut til at det som Andreassen - som selv er økonom - beskylder politikerne for, er at de har lyttet for mye til økonomer i utformingen av sin økonomiske politikk. Dette inntrykket forsterkes når man reflekterer over nøyaktig hvilke feilantagelser politikerne angivelig har gjort seg skyldige i. Nemlig (1) at de økonomiske aktørene stort sett har visst sitt eget beste, og (2) at hvis hver enkelt økonomisk aktør fremstår som solid, så må økonomien som helhet være stabil. Disse to antagelsene sier essensielt at økonomien består av individuelle, rasjonelle aktører - av arten homo oeconomicus $^{3}$ om man vil - og at økonomien derfor tilfredsstillende kan forstås på grunnlag av matematiske modeller for individuelle, rasjonelle valg (jf. Silberberg \& Suen 2001; Turner \& Roth 2003), noe som langt på vei fremstår, i hvert fall for en opplyst legmann, som den sentrale forutsetningen for det moderne økonomifaget.

Sett i lys av dette kan det virke som at Andreassen hevder at finanskrisen skyldes at politikerne har latt seg lure av en økonomisk teori som ikke holder stikk, nemlig teorien som tar utgangspunkt i hypotesen om homo oeconomicus. Dette kan i neste omgang fortone seg som en påstand om at finanskrisen skyldes at økonomifaget som sådan bygger på feilaktige forutsetninger - og dermed at skylden for krisen til syvende og sist ligger hos $ø$ konomene og deres promotering av en feilaktig teori som grunnlag for politisk praksis. Og når dette kommer fra en person som selv er fagøkonom, endog en høyt profilert sådan, fremstår utspillet som noe paradoksalt. Hvordan kan en fagøkonom kritisere politikerne for å ha «kjøpt» ideen om 
homo oeconomicus - uten å samtidig fordømme seg selv og sin stand, som tross alt var de som i sin tid «solgte» denne ideen til politikerne?

Dette paradokset oppløser seg imidlertid hvis vi registrerer at Andreassens utspill byr på to tolkningsmuligheter. Den ene muligheten er at Andreassen anser hypotesen om homo oeconomicus (i tillegg til den nært beslektede hypotesen om effektive markeder, jf. Mosini 2008) for å fremdeles utgjøre en grunnforutsetning i samfunnsøkonomifaget - og da virker det temmelig paradoksalt for ham som samfunnsøkonom å klandre politikerne for å ta denne hypotesen på alvor. Den andre muligheten er at Andreassen anser hypotesen om homo oeconomicus som ikke lenger gjeldende som en standard grunnforutsetning for økonomifaget - noe han øyensynlig mener «alle» burde ha fått med seg.

Det er denne andre muligheten jeg anser for å være mest plausibel, men samtidig på mange måter mest bekymringsverdig. For hvordan skal «alle» - politikere og legfolk - få med seg dette, det vil si at hypotesen om homo oeconomicus ikke lenger er en standard grunnforutsetning for samfunnsøkonomifaget, hvis ikke samfunnsøkonomene selv flagger det på en klar og tydelig måte i offentligheten? Med dette mener jeg selvfølgelig ikke å antyde at samfunnsøkonomene skal holde offentligheten løpende orientert om alle utviklinger i faget, men jeg mener å antyde at hvis virkelig paradigmatiske grunnforutsetninger - med massive praktiske implikasjoner for politikk, forvaltning, næringsliv og privat husholdning - ikke lenger omfattes av en bred konsensus i faget, så burde samfunnsøkonomiprofesjonen påta seg et ansvar for at dette blir flagget («disclosed», hvis man vil) klart og tydelig i den offentlige sfære. Om ikke av annen grunn så for at politiske og økonomiske aktører ikke skal kunne spekulere i legmannens manglende oppdatering på samfunnsøkonomifronten.

Jeg innser naturligvis at ikke alle samfunnsøkonomer oppfatter sin egen rolle på denne måten. For eksempel skriver Eric Nævdal, post.doc.stipendiat ved Økonomisk institutt, UiO, det følgende i en kronikk på Dagbladet.no:

Det er ingen tvil om at økonomiske resonnementer legger premissene for mye av dagens politikk. Men dette er ikke fagøkonomenes feil! Særlig siden deler av den politikken som begrunnes med økonomiske resonnementer er sludder. (Nævdal 2008)

Nævdal fortsetter med å konstatere at «som fagøkonom registrerer jeg at denne prosessen foregår, men på vegne av norsk samfunnsøkonomi nekter jeg å ta skylden for den», og avfeier samtidig mye av kritikken mot samfunnsøkonomifaget som «reinspikka tøv», noe "enhver som har fulgt med i økonomisk forskning siden 1950» burde vite. Det er nettopp denne holdningen jeg anser for å være problematisk. Nemlig at de som vet bedre (fordi de faktisk har, på skattebetalernes regning, fulgt med i økonomisk forskning 
siden 50-tallet), og som faktisk har en faglig autoritet til å «arrestere» politiske og økonomiske aktører som forvrenger eller misbruker samfunnsøkonomisk teori i offentligheten, nekter å ta noe ansvar for dette, og dermed gjennom sin taushet indirekte gir misbruket og forvrengningene legitimitet. Det er derfor det fremstår for meg som bakvendt når fagfolk som Andreassen og Nævdal (etter at krisen er et faktum vel og merke) i hissige kronikker langer ut til høyre og venstre mot alle de som ikke har fått med seg at hypotesene om rasjonelle aktører og effektive markeder ikke lenger regnes som pålitelige samfunnsøkonomiske grunnforutsetninger, samtidig som de selv representerer profesjonen som i første omgang påprakket offentligheten disse grunnforutsetningene, og som qua profesjon ikke har gjort noe systematisk forsøk på å korrigere disse oppfatningene når de er blitt forbigått av nyere forskning.

Imidlertid er jeg ikke ute etter å «ta» Andreassen eller Nævdal som enkeltpersoner, for jeg understreker at jeg hele tiden snakker om fagmiljøer, profesjonskulturer, utdanningssystemer etc. Snarere er jeg ute etter å oppfordre samfunnsøkonomene til selv å reflektere over sitt eget utdanningssystem og sin egen fagkultur, fremfor alt med hensyn til dilemmaene som oppstår i skjæringspunktet mellom økonomisk teori og økonomisk praksis. La oss nå se nærmere på denne problematikken.

\section{Okonomifaget: teori eller praksis?}

Det første man kan spørre seg om i denne sammenhengen, er hvorvidt samfunnsøkonomi skal regnes som et praktisk fag, med et dertil hørende praktisk ansvar, eller om det er et autonomt teorifag på lik linje med for eksempel matematikk eller litteraturteori. Kan ikke samfunnsøkonomene forutsette hva de vil, for sine egne intellektuelle formål, og så får de som eventuelt anvender teoriene, selv ta ansvaret for om forutsetningene for teorien stemmer med virkeligheten? Det vil si at noen andre får bekymre seg om aktørene faktisk er rasjonelle eller ikke, om markedene er effektive eller ikke, og hva dette måtte implisere for det praktiske liv. Man kunne dermed i prinsippet hevde at samfunnsøkonomifaget per se er en ren vitenskap uten direkte implikasjoner for verken økonomisk politikk eller annen økonomisk praksis. Dette synet står imidlertid i strid med hvordan faget presenteres overfor økonomistudenter ved universiteter og høyskoler, og dermed overfor offentligheten for øvrig. Hvis vi for eksempel går inn på hjemmesidene til Universitetet i Oslo, kan vi lese at «samfunnsøkonomi er aktuelt for deg som er opptatt av samfunnets mekanismer og økonomiske problemstillinger, såvel nasjonale som internasjonale, og som også er opptatt av hvordan man kan forstå, formulere og løse spesifikke samfunnsspørsmål». ${ }^{4}$ 
Når det gjelder jobbmuligheter blir vi fortalt at en bachelorgrad i samfunnsøkonomi vil

gi mulighet for jobber som saksbehandler og utreder i stat, kommuner og organisasjoner og privat virksomhet som for eksempel bank og forsikring. Med en mastergrad vil det åpne seg ytterligere muligheter for jobber på høyt nivå i forvaltning, næringsliv og internasjonale organisasjoner. Arbeidsområdene spenner over økonomisk politikk, industri, finans, journalistikk, helse u-hjelp og miljø. ${ }^{5}$

Samfunnsøkonomi blir dermed presentert av landets ledende universitet og økonomiske fagmiljø som et praktisk rettet fag som kvalifiserer til en lang rekke viktige stillinger i samfunnet. Den samme holdningen finner vi uttrykt i lærebøkene som utgjør innføringspensum for samfunnsøkonomistudenter verden over: Økonomi er et praktisk fag med de største konsekvenser for samfunnslivet. Nobelprisvinner Paul A. Samuelson åpner for eksempel den 7. utgaven av sin Economics med følgende patosfylte anslag:

As humanity welcomes the new century, economics as a science and as a subject continues to be central to the concerns around the globe. (Samuelson \& Nordhaus 2001: 1)

Eller kortere, om enn ikke så mye mer beskjedent, åpningsordene i læreverket til Begg, Fischer og Dornbusch (2005: 1): «Economics is all around you.» Det kunne vært gitt flere eksempler på denne typen retorikk fra økonomiske institusjoner og lærebøker, men det er unødvendig - det hersker liten tvil om at samfunnsøkonomifaget blir «solgt» til omverdenen på bakgrunn av sin praktiske anvendelighet. Poenget med disse sitatene er derfor bare å illustrere at hvis fagøkonomer prøver å hevde at deres fag er en «ren» vitenskap, og at de derfor ikke bærer noe moralsk ansvar for de praktiske implikasjonene av faget og dets grunnleggende antagelser, så har de et betydelig forklaringsproblem med hensyn til hvordan de presenterer seg selv og sitt fag overfor studenter og offentligheten for øvrig. Men en slik ansvarsfraskrivelse ville uansett falle på sin egen urimelighet når man ser i hvor stor grad samfunnsøkonomer og samfunnsøkonomiske teorier de facto har en sentral plassering både når det gjelder utformingen av offentlig politikk og når det gjelder det generelle økonomiske liv, ikke minst slik det utfolder seg i banker og finansinstitusjoner (jf. Ringstad 2004; Steigum 2007).

Dette ankepunktet gjør seg enda sterkere gjeldende når man tar i betraktning at samfunnsøkonomifaget inntar en dominerende posisjon som akademisk premissleverandør for økonomisk politikk, det vil si på bekostning av andre samfunnsvitenskaper som sosiologi, psykologi, antropologi etc. De eneste som muligens kunne tenkes å utfordre samfunnsøkonomene i så måte, er juristene, og selv disse vil neppe kunne fremstå som noe annet enn en god nummer to. Som Arne Næss tørt konkluderer i Økologi, samfunn og livsstil: «Sosialøkonomi er den eneste vitenskap med 
direkte, kontinuerlig innflytelse på økonomisk politikk.» (Næss 1999: 207). Og i The Economist blir følgende påpekt: «[...] on the public stage, economists were seen as far more trustworthy than politicians» (The Economist 2009: 11). Samfunnsøkonomene har altså etter alle solemerker nytt godt av (a) en unik posisjon i offentligheten, og (b) en høy grad av tillit fra publikum. Samfunnsøkonomer har med andre ord spilt en privilegert rolle når det gjelder å legge premissene for, utforme, og faktisk gjennomføre økonomisk politikk. Og privilegier forplikter.

Det er derfor ikke vanskelig å finne et rasjonale for å fremme en påstand om at i den grad økonomifaget med ulike virkemidler konstituerer seg selv som en disiplin med umiddelbare praktiske anvendelser og konsekvenser, så bærer økonomene også et moralsk ansvar for måten faget oppfattes av offentligheten på. Dette er en problematikk Paul Krugman er inne på i sin nekrolog over Milton Friedman, hvor han bemerker faren for at økonomer, ved å overforenkle sine budskap og ved å skjule forutsetningene for sine konklusjoner, krysser den hårfine skillelinjen mellom akademikere og apologeter, og det på en måte som ikke alltid er like lett å gjennomskue for offentligheten. Som Krugman skriver i The New York Review of Books:

Milton Friedman played three roles in the intellectual life of the twentieth century. There was Friedman the economist's economist, who wrote technical, more or less apolitical analyses of consumer behavior and inflation. There was Friedman the policy entrepreneur, who spent decades campaigning on behalf of the policy known as monetarism [...] Finally, there was Friedman the ideologue, the great popularizer of free-market doctrine [...] But there's an important difference between the rigor of his work as a professional economist and the looser, sometimes questionable logic of his pronouncements as a public intellectual. While Friedman's theoretical work is universally admired by professional economists, there's much more ambivalence about his policy pronouncements and especially his popularizing. And it must be said that there were some serious questions about his intellectual honesty when he was speaking to the mass public. (Krugman 2007)

Det generelle poenget vi kan trekke ut av Krugmans vurdering av Friedman, er at i overgangen mellom teori og praksis settes økonomenes intellektuelle redelighet (dvs. deres vilje til transparens) på en hard prøve; en intellektuell redelighet som er av den største betydning for alle akademikere og vitenskapsfolk, men som får en helt spesiell betydning innenfor et fag som nyter en så sentral og privilegert rolle som premissleverandør for det praktiske liv. Dette impliserer i mine øyne et visst ansvar for at faget har et noenlunde gjennomsiktig image i offentligheten, det vil si at samfunnsøkonomene tegner et så klart og ryddig bilde av sitt fag at det ikke blir mulig for økonomiske og politiske aktører å spekulere i en gråsone av aktuell og forbigått vitenskap. Med dette for øyet burde fagmiljøet ideelt sett (1) foreta en betimelig «disclosure» av eventuelle splittelser i konsensus, slik at (2) publikum kan skaffe seg en grunnleggende formening om hva som er kontrover- 
sielt og ikke innenfor samfunnsøkonomien, samt (3) hvilke prinsipielle følger disse kontroversene har for de store linjene innenfor reguleringstiltak, pengepolitikk, strukturering av finansprodukter etc.

\section{Et sporsmål om image}

For å utdype denne problematikken vil jeg se litt nærmere på økonomifagets image og hvordan det stemmer med den faglige virkeligheten. Spesielt ønsker jeg å fokusere på det fenomenet at «folk flest» later til å tro at økonomifaget er svært enhetlig, og at det derfor bare finnes én økonomifaglig «sannhet» - eller kanskje mer relevant: kun ett sett av mulige analytiske forutsetninger. Dette er et fenomen Dani Rodrik, professor i internasjonal politisk økonomi ved Harvard peker på i en artikkel gjengitt på Aftenposten.no med tittelen «Økonomene har skylden»:

Ikke-økonomer har en tendens til å se på økonomi som en disiplin som idealiserer markedene og har et snevert begrep om fordelingsvirkninger. Dersom det eneste kurset i økonomi som du har tatt er de vanlige oversiktene i introduksjonskursene, eller hvis du er journalist som spør en økonom om et kjapt svar på et politisk spørsmål, er det faktisk hva du får. (Rodrik 2009)

Dette er imidlertid ifølge Rodrik en oppfatning som ikke stemmer helt med realitetene, noe Andreassen, Nævdal og mange andre fagfolk utvilsomt ville si seg enig i. Den yter lite rettferdighet til økonomifagets etter hvert ikke ubetydelige mangfold og, kanskje like interessant, den faglige uenigheten og usikkerheten som følger derav. ${ }^{6}$ For som Carl-Erik Schultz skriver i RØST:

Er økonomer enige om noe som helst? Bør vi være - eller bli - enige om det meste? [...] Jeg mener at folk utenfor vårt fagmiljø overvurderer hvor enige økonomer er. Vi er nok enige om noen ting - men ellers spriker folk i vårt fag som de fleste andre i alle retninger. (Schultz 2005: 14)

Jeg er i høyeste grad enig med Rodrik og Schultz i at folk utenfor det økonomiske fagmiljøet overvurderer hvor enige økonomer er. Dette fremgår for eksempel av Paul Krugmans omfattende artikkel i The New York Times i september 2009, med tittelen «How did economists get it so wrong?» (Krugman 2009b), hvor han redegjør for splittelsen i den samfunnsøkonomiske konsensus, et poeng som også ble drøftet av The Economist i juli (The Economist 2009: 69). Så det kan være liten tvil om at offentligheten har hatt et fordreid inntrykk av selve samfunnsøkonomifaget - når det gjelder både dets enhetlighet og dets generelle soliditet. Men i mine øyne er dette noe økonomene selv må ta ansvar for. Med det mener jeg, som antydet ovenfor, at all den stund økonomene tilstreber en privilegert rolle som premissleverandører for økonomisk praksis, burde det være en del av deres yrkesetikk 
at de også påtar seg å korrigere eventuelle misoppfatninger om faget. For hvem andre skulle gjøre det?

Det bekymringsverdige er imidlertid at det omvendte ser ut til å ha funnet sted. Ledene fagfolk, ivrige etter å gi sine egne påstander mest mulig tyngde, har selv bidratt til å skape et utilbørlig forenklet og implisitt heroiserende bilde av samfunnsøkonomien, som på ingen måte indikerer overfor publikum at faget pr. i dag faktisk er «blindsided and divided.» (The Economist 2009: 11). For eksempel har en ruvende skikkelse som Alan Greenspan slått an tonen i så måte, med en av andre økonomer stilltiende godtatt sammenblanding av rollene som vitenskapsmann, ideolog og økonomisk/politisk aktør. Som New York Times skriver i en artikkel om årsakene til finanskrisen:

As the long-serving chairman of the Fed, the nation's most powerful economic policy maker, Mr. Greenspan preached the transcendent, wealth-creating powers of the market. A professed libertarian, he counted among his formative influences the novelist Ayn Rand, who portrayed collective power as an evil force set against the enlightened self-interest of individuals. In turn, he showed a resolute faith that those participating in financial markets would act responsibly. (Goodman 2008)

Greenspan har for øvrig selv innrømmet sin medvirkning til finanskrisen. For eksempel, som gjengitt av New York Times:

Referring to his free-market ideology, Mr. Greenspan added: «I have found a flaw. I don't know how significant or permanent it is. But I have been very distressed by that fact.»

Mr. Waxman pressed the former Fed chair to clarify his words. «In other words, you found that your view of the world, your ideology, was not right, it was not working,» Mr. Waxman said.

«Absolutely, precisely,» Mr. Greenspan replied. "You know, that's precisely the reason I was shocked, because I have been going for 40 years or more with very considerable evidence that it was working exceptionally well.» (Leonhardt 2008)

Offentlige skikkelser som Greenspan har altså bidratt med sin posisjon og prestisje til å fremelske et inntrykk av at den økonomiske vitenskap ikke bare er fundert på et solid og entydig grunnlag, men at dette grunnlaget legitimerer en liberalistisk (for ikke å si liberteriansk) dyrkelse av det suverene individ, som passer som hånd $\mathrm{i}$ hanske med tanken om homo oeconomicus som den grunnleggende analytiske enhet i faget. Og selv om det finnes fagfolk som har protestert offentlig mot dette, har de vært i mindretall. Det store flertallet av samfunnsøkonomer har dermed enten opptrådt som aktive apologeter for dette synet, eller som passive tilskuere - og det er kanskje det siste som er det verste.

Takket være den tause majoriteten av samfunnsøkonomer som ikke samlet seg til protest mot de tendensiøse forenklingene av faget, ble offentligheten sittende med et inntrykk av at det å forsvare visse former for mar- 
kedsøkonomi er ensbetydende med å forsvare samfunnsøkonomifaget som sådan, som i sin tur blir sett på som ensbetydende med å forsvare tanken om det rasjonelle, suverene individ som den eneste opplyste forståelseshorisont for menneskelig handling. Våre hjemlige kommentatorer har i stor grad støttet opp om dette bildet, med lite motbør fra faglig hold. For eksempel skriver Aftenpostens Øystein Sjølie følgende på nettstedet E24, hvor han er fast spaltist:

Grunnleggende for den deskriptive, eller beskrivende, delen av økonomien er en sterk tillit til enkeltmennesket. Den sentrale forutsetningen i økonomifaget er at mennesker er rasjonelle. De er ikke allvitende, men stort sett i stand til å innhente den informasjonen de trenger, og til å vurdere valgmulighetene de har, for å nå sine mål så godt som mulig. (Sjølie 2008)

Dette fremstår for meg som et godt eksempel på en tendensiøs beskrivelse av økonomifaget. Og formålet med beskrivelsen er tilsvarende polemisk. Den inngår i et svar til Bernt Sofus Tranøy og alle andre som tydeligvis ikke (i Sjølies øyne) har forstått hva samfunnsøkonomi dreier seg om (jf. Tranøy 2007). Som Sjølie fortsetter:

Tranøys anklager om å se på mennesket som «kalkulasjonsmaskiner» er enda merkeligere. Nesten alle mennesker er jo i stand til å utføre ekstremt avanserte beregninger, svært hurtig. Tenk bare på hvor mange som klarer å slå til en ball i luften med en tennisracket. Svært få klarer å beskrive disse beregningene meningsfylt, men de fleste klarer å utføre beregningene. Økonomiske avveininger fungerer på samme måte. Hvis man får tilbud om å jobbe en time overtid, innebærer det både fordeler og ulemper. De fleste klarer å gjøre denne avveiningen raskt, uten at de klarer å beskrive avveiningen særlig presist. De fleste klarer også å gjøre slike avveininger relativt presist. Riktig nok angrer de fleste av oss på dårlige kjøp, men ganske sjelden med tanke på hvor ofte vi handler. (Sjølie 2008)

Hva Bernt Sofus Tranøy mener og ikke mener, er ikke noe som direkte berører mitt anliggende her. Grunnen til at jeg trekker frem disse sitatene, er at de tjener som eksempel på den typen ideologisk forsvar for økonomifaget som mobiliseres i møte med visse typer ideologiske angrep på faget. Angrep og forsvar som karakteristisk nok fokuserer på homo oeconomicus, og som derfor sementerer det generelle inntrykket av at det er dette økonomifaget $\mathrm{i}$ all vesentlighet handler om. Men er det egentlig så enkelt? Svaret fremstår for meg som et klart nei; det er ikke så enkelt. Men da melder neste spørsmål seg, som etter min mening er det virkelige spørsmålet: Hvem har ansvaret for å korrigere dette forenklete inntrykket? Politikerne? Forvaltningen? Næringslivet? Folk flest? Eller fagfolkene? Konklusjonen gir seg nesten selv - ingen andre enn fagfolkene er i posisjon til å ivareta denne funksjonen.

Hvis vi skal trenge dypere inn i vår problemstilling, kommer vi derfor ikke unna en nærmere kikk på samfunnsøkonomifaget som sådan. Først 
når vi får et visst innblikk i de teoretiske komplikasjonene ved samfunnsøkonomifaget får vi en viss fornemmelse av faremomentene som oppstår når teorien skal formidles til offentligheten - samt en fornemmelse av nødvendigheten av at fagfolkene selv tar ansvar for å korrigere offentlighetens oppfatning av hva samfunnsøkonomi faktisk er, etter hvert som faget utvikler seg.

Så hva mener jeg da er misvisende med påstandene til Sjølie om at grunnlaget for den «deskriptive, eller beskrivende, delen av økonomien er en sterk tillit til enkeltmennesket» og at den «sentrale forutsetningen i økonomifaget er at mennesker er rasjonelle»? For det første kan man påpeke (ankepunkt nr. 1) at Sjølie glemmer 50 prosent av økonomifaget, nemlig makroøkonomien. I makroøkonomien er det ikke spesielt treffende å si at man har en «sterk tillit til enkeltmennesket», for man opererer med aggregater og ikke enkeltindivider (se f.eks. Steigum 2007). Interessant nok avspeiles dette $i$ at makroøkonomi på mange måter har vært den moderate venstresidens prosjekt fra Keynes og utover. ${ }^{7}$ Det Sjølie gjør, er å beskrive den mikroøkonomiske tenkemåten, og hva mer er (ankepunkt nr. 2), tenkemåten innenfor den mest forenklede, neoklassiske mikroøkonomien - som man i visse henseender kan si har vært høyresidens prosjekt opp igjennom årene. Vi skal for øvrig straks se at selv ikke den mikroøkonomisk funderte teorien lenger er hva den en gang var når det gjelder rasjonalitetsforutsetninger (jf. Akerlof 2002).

Ved å underslå disse poengene får Sjølie det til å se ut som at økonomifaget som helhet er identisk med den neoklassiske mikroøkonomien, og skreddersydd for høyresidens politiske prosjekter. I realiteten utgjør denne type anskuelser, som Eric Nævdal (2008) påpeker i sitt innlegg, en heller ensidig oppfatning av samfunnsøkonomien. Å fremstille dette synet som konsensus i økonomifaget er en tilsnikelse, noe Nævdal gjør klart i sitt innlegg. Men det ironiske er at Nævdal i dette innlegget ikke investerer sin kunnskap og autoritet i å korrigere Espen Sjølie og hans likesinnede, og dermed også sette søkelys på hvordan Sjølie bruker sin posisjon som økonomisk kommentator på E24 til å holde i gang et ideologisk farget prosjekt med tvilsom faglig underbygging, men i stedet hakker løs på relativt harmløse kritikere som Bernt Sofus Tranøy og Erik Reinert. For til syvende og sist fremstår Sjølie som en langt farligere venn for samfunnsøkonomien enn Tranøy og Reinert er fiender - det er nemlig apologeter som Sjølie som gir ammunisjon til kritikere som hevder at samfunnsøkonomien er både intellektuelt suspekt og politisk tendensiøs.

Med andre ord: Hvis de samfunnsøkonomiske miljøene ved UiO og andre institusjoner hadde brukt sin faglige autoritet til å korrigere lettvinte økonomiske journalister og kommentatorer, ville kritikken fra folk som Tranøy og Reinert mistet noe av sin brodd. Og om ikke annet måtte kritikernes påstander stå for deres regning, mens Sjølie kontinuerlig fører sine 
påstander på samfunnsøkonomenes regning - en regning de pr. i dag konfronteres med. Det er dette poenget Jonas Hjort henleder oppmerksomheten på i et tilsvar til både Sjølie og Bernt Sofus Tranøy, hvor han klokelig påpeker at heller ikke på mikronivå, hvor den enkelte aktør kommer inn i bildet, tar man lenger for gitt det neoklassiske synet på likevekt og rasjonalitet:

På 1970-tallet oppdaget makroøkonomer at deres modeller førte til betydelig mer elegante forutsigelser hvis en simpelthen antok at alle mennesker var rasjonelle. Antakelsen banet vei for spennende nye temaer og vips ble - trolig for første gang i fagets historie - en enkel antakelse til en akseptert grunnstein i nyklassisk $ø$ konomi uten noen gang å ha vært en testet hypotese [...]

Psykologene Amos Tversky og Daniel Kahneman, som vant Nobelprisen i økonomi i 2002, gjorde heldigvis oss økonomer den store tjenesten å minne oss på universal-rasjonalitetens urimelighet. Slik oppsto feltet «behavioral economics» eller adferdsøkonomi, som nå holder på å revolusjonere hele samfunnsøkonomien som vitenskap, ved bruk av mer realistisk teori og resultater fra psykologi $[\ldots]$

Øystein Sjølie slår et nyklassisk slag mot Tranøy i E24 og sammenligner Tranøy med Don Quijote som innbiller seg at han kjemper mot onde kjemper. Metaforen er perfekt, men paradoksalt nok (for Sjølie) fordi tradisjonell nyklassisk økonomi nå er å anse som gårsdagens vitenskap. (Hjort 2008, min kursivering)

Hvis man først anerkjenner dette poenget, anerkjenner man samtidig at retorikken om marked, frihet og rasjonalitet man til tider hører, ikke bare fra journalister som Sjølie, men også fra høyt skolerte og høyt plasserte økonomer, faktisk ikke har den entydige vitenskapelige fundamentering som enkelte liker å gi inntrykk av - jf. Alan Greenspan og Milton Friedman. Det samme poenget gjelder selvfølgelig for venstresidens apologeter, som har vel så mye å svare for, enten de støtter seg på Marx eller Keynes. For uansett faglig orientering og politiske sympatier er det bare så altfor fristende å insinuere at ideologiske posisjoner følger logisk fra vitenskapelige teorier; det er derfor det er så viktig med visse etisk-epistemolgiske retningslinjer vi kan bruke som utgangspunkt for å korrigere både oss selv og andre når denne fristelsen tar overhånd.

\section{Profesjonsetikk for samfunnsokonomer - trengs det?}

Stilt overfor eksesser på begge sider av det politiske spektrum, virker det ikke unaturlig å etterlyse et profesjonsetisk ideal for samfunnsøkonomer som fremelsker nøkternhet og ydmykhet overfor faget og dets anvendelser. For, som Dani Rodrik skriver:

Økonomi er virkelig et verktøy med flerfoldige modeller - hver av dem gir en ulik, stilisert fremstilling av noen aspekter av virkeligheten. Å være dyktig økonom 
avhenger av evnen av å plukke og velge den rette modellen for en gitt situasjon. Økonomifagets rikdom har ikke gjenspeilet seg i den offentlige debatten fordi økonomene har krevd for stor autorisasjon. I stedet for å presentere en meny med muligheter og sette opp en liste med relevante valgmuligheter - noe som økonomi handler om - har økonomene for ofte overført sine egne sosiale og politiske innstillinger. I stedet for å være analytiske, har de vært ideologer som har favorisert ett sett av sosiale ordninger fremfor andre. (Rodrik 2009)

Det å presentere en «meny med muligheter» og "sette opp en liste med relevante valgmuligheter» ville vært i tråd med Keynes’ ønske om at økonomer en dag skulle bli som tannleger: en profesjon som qua profesjon fokuserer, i så høy grad som det er menneskelig mulig, på det praktiske og funksjonelle fremfor det ideologiske. ${ }^{8}$ Med dette mener jeg selvfølgelig ikke at økonomer ikke skal ha lov til å ta opp ideologiske spørsmål - jeg mener kun at de ikke skal få lov til å ta opp slike spørsmål samtidig som de dekker seg under påstanden om at de «bare» driver med samfunnsøkonomi, og derfor er hevet over alle som sysler med ideologiske problemstillinger på en mindre vitenskapelig basis. Gjør man dette, hengir man seg bevisst til en intellektuelt uredelig sammenblanding av utsigelsesposisjoner, og gjør seg til syvende og sist skyldig i, som Carl-Erik Schultz antyder, utøvelsen av en hersketeknikk. ${ }^{9}$ Schultz formulerer problemet slik:

Forutsetningene vi gjør er ofte en blanding av hva som er fruktbart for å forstå, og hva hver enkelt mener at skal til for å få andre til å godta slutninger en sjøl mener er riktige. Her har vi [samfunnsøkonomer], som andre, lett for å la munnen løpe over med det hjertet er fylt av. Problemet er hvis en ikke sier fra hva slags analyse og forutsetninger man gjør. Økonomiske argumenter for interessekamp er bra, men ofte ser en at ønsket konklusjon bestemmer forutsetningene. Dette er en ganske vanlig form for å overkjøre meningsmotstandere med begrenset økonomisk kompetanse. (Schultz 2005: 15)

Det virker derfor ikke bare klokt, men også i en viss forstand moralsk påkrevd for økonomer å avstå fra tendensiøse forenklinger, og heller konsentrere seg om å gi publikum en nøktern oversikt over hvilke samfunnsøkonomiske teknikker som faktisk finnes, og i hvilke situasjoner (dvs. under hvilke forutsetninger) de har vist seg henholdsvis egnede og uegnede. Fremfor alt mener jeg at dette idealet medfører et kollektivt ansvar innenfor samfunnsøkonomiprofesjonen for å gi offentligheten et realistisk bilde av usikkerhetsmomentene i faget, for det er disse momentene publikum trenger en viss innsikt i for å kunne vurdere den vitenskapelige underbyggingen av - og dermed også risikoene forbundet med - agendaene til ulike økonomiske og politiske aktører.

Mitt overordnede poeng er altså at samfunnsøkonomer må være ekstremt forsiktige med hvordan de henvender seg og eventuelt ikke henvender seg til offentligheten, og at dette i en viss forstand konstituerer et etisk krav til profesjonen. Jeg vil igjen understreke at det dreier seg om pro- 
fesjonen som helhet; det holder til syvende og sist ikke å bruke enkelte annerledestenkende økonomer som Joseph Stigliz (jf. Stiglitz 2002) som alibi for at «økonomene tar ansvar», spesielt ikke så lenge disse fremdeles fremstilles som alternative økonomer. Mitt poeng er nettopp at jeg ikke hevder at $ø$ konomene burde ha forholdt seg til en alternativ økonomisk teori de burde snarere ha formidlet et bedre bilde av økonomifaget som helhet, med alle sine teorier, og med de begrensinger og usikkerheter som hefter ved enhver økonomisk teori, enten den er alternativ eller ikke. Som Rodrik påpeker:

Ingen økonom kan være helt sikker på at hans foretrukne modell er korrekt. Men når han og andre gjør seg til talsmenn for å utelukke alternativer, ender de opp med å kommunisere en svært overdrevet grad av tiltro til hvilken utvei som er påkrevet. Paradoksalt nok gjenspeiler kanskje forvirringen innen faget nå bedre profesjonens virkelige verdi enn tidligere tiders misvisende enighet. Økonomer kan i beste fall klargjøre valgene som politikerne står overfor, men de kan ikke ta valgene for dem [...] Når økonomer er uenige, får verden innblikk i forskjellige syn på hvordan økonomien virker. (Rodrik 2009)

Fra et vitenskapsteoretisk synspunkt ligger det mest kritikkverdige forholdet $\mathrm{i}$ at samfunnsøkonomene ikke ser ut til å ha lykkes $\mathrm{i}$ å formidle til offentligheten at samfunnsøkonomiske teorier i ordets rette forstand bare er teorier. Innsikten i at teorier bare er teorier (dvs. hypotetiske og feilbarlige), en innsikt vi som akademikere har ansvar for å forvalte innenfor våre respektive fagområder, danner ikke bare grunnlaget for den vitenskapelige metoden, men også, som Karl Popper påpeker, selve grunnlaget for det åpne samfunn (Popper 1963; 2002). Med andre ord kan man si at de basale normene for vitenskapelig etterrettelighet, som formulert av Popper og andre, i sin essens ikke utgjør annet enn «føre var»-prinsipper som har som sin viktigste funksjon å legge en demper på den «irrational exuberance» som Popper identifiserte med ideologiske prosjekter, og som hans elev George Soros gjenkjente i finansmarkedene (Soros 2003).

Tilsvarende kunne man mistenke at hvis fagøkonomene hadde brukt litt mindre tid og krefter på å diskreditere noen få marginale røster, som for eksempel Tranøy og Reinert i Norge (som faktisk har gitt et nyttig bidrag til tematiseringen av hva samfunnsøkonomi betyr i praksis), og i stedet hadde konsentrert seg om å opplyse offentligheten på en saklig måte om de vitenskapsteoretiske begrensningene ved økonomisk prediksjon og teoridannelse, kunne de bidratt til temmingen av den grunnleggende økonomiskpolitiske «irrational exuberance» som nå stort sett «alle», både leg og lærd, er enige om at har mye av skylden for finanskrisen. I tråd med dette vil jeg antyde at nettopp tema som varsomhet og det å være føre-var kan danne et nyttig fokus for en kombinert epistemisk og profesjonsetisk refleksjon over 
hva det i praksis vil si å være samfunnsøkonom, og som med fordel kunne vært integrert i utdanningen av nye generasjoner av samfunnsøkonomer.

\section{En «vær varsom»-plakat for samfunnsøkonomer}

Det finnes et ordtak som sier at «det trengs en tyv for å fange en tyv». Ut fra samme tankegang vil jeg si at det trengs en samfunnsøkonom for å «arrestere» en samfunnsøkonom. For eksempel kan jeg som filosof ikke arrestere samfunnsøkonomer på et samfunnsøkonomisk grunnlag, men det jeg kan gjøre, er å arrestere samfunnsøkonomer for å være for dårlige til å arrestere hverandre når det gjelder å trå over grensene for faglig etterrettelig opptreden i offentligheten. Det vil si at jeg er i min fulle rett som borger og filosof til å anmode samfunnsøkonomene - deres privilegerte stilling i offentligheten tatt $\mathrm{i}$ betraktning - om å sette seg ned og tenke nøye igjennom hvordan de, som så mange andre profesjoner, skal utøve en indre justis som står i forhold til deres samfunnsoppdrag, en indre justis som også har et didaktisk aspekt når det gjelder hvordan nye generasjoner av yrkesutøvere skal sosialiseres inn i disse normene for saklighet og etterrettelighet.

Eksempelvis har det i den senere tid, ikke minst i anledning finanskrisen, vært et økende fokus på etikk i forbindelse med skoleringen av det som for enkelhets skyld kan kalles for bedriftsøkonomer, eller om man vil, i forbindelse med de merkantile utdannelser. ${ }^{10}$ Både Aftenposten og Dagens Næringsliv har trykket en rekke saker og innlegg om dette temaet. På Harvard Business School har til og med en student, Maxwell Anderson, tatt initiativ til innføringen av en «hippokratisk ed» som skal sette søkelys på næringslivslederens etiske forpliktelser og idealer. Og ved Handelshøgskolen i Bodø (hvor jeg selv underviser) må studentene gjennomgå et obligatorisk kurs i Filosofi, etikk og miljø i forbindelse med mastergraden. Dette er vel og merke et praktisk rettet kurs som blir undervist av folk med bedriftsøkonomisk kompetanse, for eksempel innenfor miljøsertifisering og «corporate social responsibility». I tillegg får studentene en mer akademisk og historisk betont innføring i etisk, politisk og metodologisk tenkning gjennom ex.phil., som er en del av bachelorstudiet. Nå er jeg selvfølgelig på det rene med at det er delte meninger både mellom og innad på handelshøyskolene angående hvilken form og hvilket omfang denne typen skolering skal ha, men det er liten tvil om at man i miljøet mener at noe slikt er påkrevd om ikke annet så er det i hvert fall en debatt som eksisterer og blir tatt på alvor.

Mitt spørsmål blir da: Hvis bedriftsøkonomens moralske ansvar for det $ø$ konomiske liv tas så alvorlig av lærestedene at det tematiseres eksplisitt $\mathrm{i}$ utdannelsen og dannelsen av den faglige identiteten, hva da med samfunns$ø k o n o m e n e ?$ Er ikke deres ansvar om mulig enda større, tatt i betraktning at 
uten det teoretiske og institusjonelle fundamentet lagt av samfunnsøkonomer kunne ikke bedriftsøkonomer utført sitt virke? Med dette i tankene og med bakgrunn i mine drøftelser ovenfor - tillater jeg meg å foreslå innstiftingen av en «vær varsom»-plakat for samfunnsøkonomer, sammen med noen forslag til punkter/prinsipper for en slik plakat. Samtidig vil jeg henlede oppmerksomheten på at i nummeret av RØST jeg har referert til i denne artikkelen, finnes det i realiteten mer enn nok materiale til å gjennomføre et slikt prosjekt, og det fra samfunnsøkonomers egen hånd. Jeg tillater meg likevel å gi mitt lille bidrag. ${ }^{11}$ For øvrig finnes det en annen lesemåte av det følgende, nemlig å se det som den opplyste legpersonens («the concerned citizen'»») oppfordring til samfunnsøkonomene om hvordan de skal henvende seg til offentligheten:

\section{Vær varsom!}

Samfunnsøkonomi er et fag med stor samfunnsmessig betydning, men hvor skillelinjen mellom ideologi og vitenskap kan være hårfin. Hvis denne skillelinjen overskrides uten at det blir gjort til gjenstand for kritisk oppmerksomhet, kan det oppstå en farlig forbindelse mellom teori og praksis. Derfor:

1 Klargjør alltid dine teoretiske forutsetninger for deg selv og andre.

2 Vær proaktiv i din klargjøring; gjør publikum oppmerksom på hvor de problematiske forutsetningene ligger.

3 Ikke forenkle en idé så mye at poenget går tapt, og lag ikke karikaturer av andres ideer.

4 Hvis det finnes mer enn én måte å se en sak på, ikke ordlegg deg på en slik måte at publikum kan få inntrykk av at din måte er den eneste.

5 Hvis du som økonom har vært med på å ta æren for gode tider i økonomien, vær også villig til å ta noe av ansvaret når problemer oppstår.

6 Hvis en økonomisk idé er for komplisert til å forklares for offentligheten, egner den seg kanskje ikke som grunnlag for offentlig politikk.

7 Hvis du ikke er i stand til å forklare grunnrisset for en økonomisk idé til en opplyst legperson, har du kanskje ikke helt forstått den selv.

8 Vær klar over, og gjør andre klar over, at samfunnsøkonomiske moteretninger svinger over tid, og gjerne i takt med de politiske konjunkturene.

9 Hvis du selv har en politisk agenda, fremhev den snarere enn å legge skjul på den.

10 Hvis andre økonomer fremsetter påstander i offentligheten som du finner faglig uetterrettelige, la dem ikke stå uimotsagt. Den som tier, samtykker!

En mulig tilnærming til en slik prinsipperklæring, kunne være å innlemme den i et emne innenfor samfunnsøkonomistudiet som tar for seg metodologiske og historiske aspekter ved økonomifaget. Slik sett kan jeg bare si meg enig i Radikalt økonominettverks tanke om at samfunnsøkonomisk fagkritikk og faghistorie hører sammen, og derfor burde presenteres i sammenheng til studentene. En slik blanding av etisk, metodologisk og historisk-politisk bevisstgjøring kunne introduseres på bachelornivå, kanskje i 
kombinasjon med ex.phil. og ex.fac., med oppfølging i forbindelse med master- og doktorgrad.

Det essensielle er imidlertid å formidle at etikk, både som noe yrkesrettet og som noe eksistensielt, har å gjøre med ansvarlighet, bevisstgjøring og hensyntagen til andre, og at det å «kjenne seg selv», for å si det med Sokrates, er et etisk prosjekt per se. Og hvorfor det? Fordi at det å kjenne seg selv henger nøye sammen med hvordan man relaterer seg til andre, og derfor kan man heller ikke skille klart mellom metodologi og moral, mellom epistemologi og etikk (Wyller 1997: 30). Selve det å komme til klarhet overfor seg selv, samt det å skape klarhet for andre, er i denne forstand i seg selv noe verdiladet, det er en form for etikk som burde ha ekstra stor relevans for samfunnsøkonomi, et fag hvor den moralske utfordringen ligger nettopp i den farlige forbindelsen mellom teori og praksis som kan oppstå når forutsetninger og agendaer tåkelegges.

Det er for øvrig betegnende at den sokratiske etikken tok form av en refleksjon over hvordan man skulle tale i offentligheten, det vil si på torget og i folkeforsamlingen, og at det grunnleggende siktemålet var nettopp å skille mellom «kunnskap» og «meninger», og i forlengelsen av dette, å skille mellom det å «overtale» og det å «overbevise» (jf. Copleston 1993; Johansen \& Vetlesen 2006; Glickman 1976; Platon 1971; 1961).

\section{Konklusjon}

Med bakgrunn i momentene som er trukket frem i denne artikkelen, er det mulig å gi et slags svar på spørsmålet: Hvilket ansvar har samfunnsøkonomene for finanskrisen? For det første må det anerkjennes at all den stund vi lever i et demokrati, er det folket og de folkevalgte som har det direkte ansvaret for den økonomiske politikken, inkludert hvordan finansmarkedene er regulert. Dernest må det erkjennes at samfunnsøkonomene har, som de fremste faglige premissleverandørene for den økonomiske politikken, et vesentlig indirekte ansvar. Alt står og faller dermed på hvordan de forvalter dette ansvaret.

Nærmere bestemt: (1) I den grad økonomene fremelsker transparens i den økonomiske diskursen og leverer nøytrale faglige premisser som gir folket og de folkevalgte en reell sjanse til selv å vurdere de mulige økonomiske tolkningsalternativene og handlingsmåtene i en gitt situasjon, så har økonomene lite ansvar for eventuelle kriser som oppstår. Men (2) i den grad økonomene tolererer uklarheter i den faglige diskursen, og på denne måten ikke legger til rette for folkets og de folkevalgtes informerte stillingtagen, så har økonomene et ansvar for eventuelle kriser som oppstår.

Spørsmålet blir da om det er (1) eller (2) som gjelder i den nåværende situasjonen. I lys av det vi har diskutert ovenfor, virker det nærliggende å si 
at mye tyder på at det er (2). Samfunnsøkonomene, som profesjon betraktet, har ikke formidlet et tilstrekkelig bredt og kritisk bilde verken av sitt eget fag eller av den økonomiske situasjonen til at folket og de folkevalgte har kunnet danne seg et realistisk bilde av den økonomiske utviklingen og de farene den har vært forbundet med. For som Rodrik understreker, har de vitenskapelige ressursene vært til stede for å forstå risikoen som har bygget seg opp - det er bare det at legmannen har fătt lite kjennskap til det:

Arbeidsmarkedsøkonomene fokuserer ikke bare på hvordan fagforeninger kan forvrenge markeder, men også hvordan de, under gitte forhold, kan øke produktiviteten. Handelsøkonomene studerer globaliseringens virkninger på ulikhetene, både innenfor enkelte land og på tvers av landegrensene. Finansteoretikerne har skrevet massevis om konsekvensene av at hypotesen om "effektive markeder» slo feil. Makroøkonomene som er spesialister i åpne økonomier, gransker ustabilitetene i internasjonal finans. (Rodrik 2009)

På grunn av denne mangelfulle "public disclosure» av hva faget egentlig går ut på, og hva det med rimelighet kan tas til inntekt for, har ulike ekstremister med Alan Greenspan i spissen fått betydelig spillerom i offentligheten. Med andre ord: Den «tause majoriteten» av økonomiske fagfolk gjorde fenomenet Alan Greenspan mulig. Ved å gjøre for lite motstand mot fremveksten av de forenklede og ideologiske fremstillingene av økonomien og økonomifaget som enkelte prominente fagfolk og deres støttespillere i media gjorde seg skyldige i, har profesjonen som sådan gjort seg medskyldig i finanskrisen. Jeg betrakter dermed Greenspan først og fremst som et symptom på en intellektuell kultur som har bidratt til en generell sammenblanding av politisk ideologi og økonomisk vitenskap i offentligheten. De hederlige unntakene i denne prosessen er for få og har mottatt for lite støtte fra den «tause majoritet» av fagøkonomer til å rette opp helhetsinntrykket.

Men nettopp fordi dette dreier seg om et kollektivt ansvar, som rammer profesjonen snarere enn den enkelte utøver, burde også responsen være tilsvarende kollektiv. Nærmere bestemt, som jeg antydet innledningsvis, kunne en passende kollektiv respons være å drøfte følgende tiltak:

1 Systematisk refleksjon over forholdet mellom teori og praksis bør gjøres til en integrert del av den samfunnsøkonomiske utdanningen.

2 Profesjonen bør søke å artikulere et profesjonsetisk grunnsyn som bidrar til å sette fokus på de farlige forbindelsene som kan oppstå mellom ulike typer og nivåer av økonomisk diskurs hvis ikke høye standarder for transparens overholdes.

Dette indikerer samtidig hvilken moralsk lærdom økonomene kan ta av krisen: Profesjonen som helhet må ta sin rolle som «fødselshjelper» for folkets økonomiske erkjennelse på alvor -jeg har det gode gamle idealet om folke- 
opplysning i tankene. Det betyr, i tråd med Sokrates' filosofi, at økonomene må legge vekt på å hjelpe folket til selv å danne seg en velfundert mening. Dette impliserer - med både Sokrates og Karl Popper i mente - at økonomene må bestrebe seg på å bryte ned fordommer og vrangforestillinger om sitt eget fag. For som Keynes hevdet og som både Sokrates og Popper utvilsomt ville si seg enig i, det vanskeligste er ikke å danne seg nye oppfatninger, men å kvitte seg med de gamle. Dermed kan det være passende å avslutte med et sitat av Keynes som på mange måter oppsummerer problemstillingen for denne artikkelen:

The ideas of economists and political philosophers, both when they are right and when they are wrong, are more powerful than is commonly understood. Indeed the world is ruled by little else. Practical men, who believe themselves to be quite exempt from any intellectual influence, are usually the slaves of some defunct economist. (Keynes 1997: 383)

En yrkesetikk for samfunnsøkonomer går i bunn og grunn ut på å handle i tråd med ansvaret dette medfører.

\section{Noter}

1 Det er mao. på mange måter en talehandlingenes etikk jeg vil drøfte. Jf. Austin (1975) og Habermas (1985a/b; 2001) angående teorien om talehandlinger og hvordan de kan ha en etisk dimensjon.

2 Med hederlige unntak naturligvis; f.eks. Dani Rodrik, en kommentator jeg vil støtte meg til nedenfor. To av RØST-forfatterne som har fått fornyet oppmerksomhet i forbindelse med krisen, er Erik Reinert og Rune Skarstein, jf. Reinert (2009) og Skarstein (2007). Se også Skarstein (1976). Blant nobelprisvinnere kan man nevne Joseph Stiglitz (2002) og Paul Krugman (2009a).

3 Uttrykket ble først brukt i forbindelse med en kritikk av J. S. Mill; jf. Turner \& Roth (2003: 144).

4 Lastet ned fra www.uio.no/studier/program/samfokon-ba/om/kort-om-programmet.xml.

5 Lastet ned fra www.uio.no/studier/program/samfokon-ba/om/jobb-og-studiemuligheter.xml.

6 Enkelte ville utvilsomt ønske seg enda mer mangfold, f.eks. Reinert (2009) og Skarstein (2007). Mitt prosjekt er i denne sammenheng imidlertid bare å påpeke at desto mer transparens og ryddighet det er i den offentlige diskursen angående økonomi, desto mer plass vil det være for alternative synspunkter gitt at de er stottet opp av saklige argumenter. Jeg er i den forstand verken tilhenger eller motstander av «alternative» økonomiske teorier per se; jeg opptrer strengt tatt bare som tilhenger av at de beste argumentene skal få gjennomslag i offentligheten.

7 Det samme gjelder for den økonometriske tradisjonen, som også er en del av samfunnsøkonomien. Jf. Haavelmo (1997) og Nerlove (1990).

8 At Keynes selv ikke oppfylte dette idealet spesielt godt, gjør det ikke mindre gyldig. 
9 For en generell diskusjon av denne typen problemstilling, jf. Habermas (1969). Se også Wright (1991).

10 Tilsvarende finnes det en omfattende litteratur om forretningsetikk, se for eksempel Boatright (2007) og Granum \& Kosberg (2003).

11 Det følgende kan betraktes som en adapsjon av den typen saklighetslære og argumentasjonsteori man finner i Næss (1975) og Toulmin (1974), og som får en eksplisitt etisk dreining f.eks. hos Habermas (1985a/b; 2001). Jf. også Wyller (1997), Rasmussen (1990) og Johansen \& Vetlesen (2006) om diskursetikken. Merk at disse problemstillingene, slik de vedkommer samfunnsøkonomien, naturlig nok vil ligne på dem man finner hos Gillund \& Myhr (2007).

\section{Litteratur}

Akerlof, G. A. (2002) Behavioral macroeconomics and macroeconomic behavior. American Economic Review, 92 (3), s. 411-433.

Andreassen, H. M. (2009) Banker i krise. Dagens Noringsliv, 26. juni 2009.

Austin, J. L. (1975) How to do things with words. Cambridge: Harvard University Press.

Begg, D., Fischer, S. \& Dornbusch, R. (2005) Economics. New York: McGraw-Hill.

Berg Astad, R. S., Sande Lie, G. S. \& Stensnes, K. (2005) Innledning. RØST 2005-01: Økonomisk teori og politisk praksis. Oslo: Radikalt økonominettverk.

Boatright, J. B. (2007) Ethics and the conduct of business. New Jersey: Pearson Education Inc.

Copleston, F. (1993) A history of philosophy, Volume I: Greece and Rome. New York: Doubleday.

Frank, R. H. (2008) Microeconomics and behavior. New York: McGraw-Hill.

Gilje, N. \& Grimen, H. (1993) Samfunnsvitenskapenes forutsetninger. Oslo: Universitetsforlaget.

Gillund, F. \& Myhr, A. I. (2007) Vitenskapelig usikkerhet - etiske utfordringer for forskning og forvaltning. Etikk i praksis, 1 (1), s. 97-120.

Glickman, J. (red.) (1976) Moral philosophy. London: St. James Press.

Goodman, P. S. (2008) Taking hard new look at a Greenspan legacy. The New York Times, 8. oktober 2008.

Granum Carson, S. \& Kosberg, N. (2003) Etisk forretning. Oslo: J. W. Cappelens Forlag.

Haavelmo, T. (1997) Econometrics and the welfare state. American Economic Review, 87 (6), s. 13-15.

Habermas, J. (1969) Vitenskap som ideologi. Oslo: Gyldendal.

Habermas, J. (1985a) The theory of communicative action, Volume 1. Boston: Beacon Press.

Habermas, J. (1985b) The theory of communicative action, Volume 2. Boston: Beacon Press.

Habermas, J. (2001) On the pragmatics of social interaction. Cambridge: The MIT Press.

Heilbroner, R. L. (1999) The worldly philosophers. New York: Simon and Schuster Ltd. 
Hjort, J. (2008) Psykologen er økonomens og statsviterens beste venn. Lastet ned 15. april 2008 fra http://e24.no/det-skjer/article2 369062 .ece

Johansen, K. E. \& Vetlesen, A. J. (2006) Innføring i etikk. Oslo: Universitetsforlaget.

Keynes, J. M. (1997) The General Theory of Employment, Interest, and Money. Amherst: Prometheus Books.

Kincaid, H. (1986) Reduction, explanation, and individualism. Philosophy of Science, 53 (4), s. 492-513.

Krugman, P. (2007) Who was Milton Friedman. The New York Review of Books, 15. februar 2007.

Krugman, P. (2009a) Finanskriser og depresjonsøkonomi. Oslo: Hegnar Media.

Krugman, P. (2009b) How did economists get it so wrong? The New York Times, 6. september 2009.

Leonhardt, D. (2008) Greenspan's mea culpa. Lastet ned 23. oktober 2008 fra http:/ /economix.blogs.nytimes.com/2008/10/23/greenspans-mea-culpa.

Mattessich, R. (1978) Instrumental reasoning and systems methodology. Dordrecht: Reidel Publishing Company.

Mosini, V. (red.) (2007) Equilibrium in economics: Scope and limits. London: Routledge.

Næss, A. (1975) En del elementore logiske emner. Oslo: Universitetsforlaget.

Næss, A. (1999) Økologi, samfunn og livsstil. Oslo: Bokklubben Dagens Bøker.

Nelson, A. (1984) Some issues surrounding the reduction of macroeconomics to microeconomics. Philosophy of Science, 51 (4), s. 573-594.

Nerlove, N. (1990) Trygve Haavelmo: A critical appreciation. The Scandinavian Journal of Economics, 92 (1), s. 17-24.

Nævdal, E. (2008) Høyrevridd samfunnsøkonomi? Lastet ned 28. februar 2008 fra www.dagbladet.no/kultur/2008/02/28/528 228.html

Platon (1961) Protagoras and Meno. London: Penguin Books.

Platon (1971) Gorgias. Oslo: Det Norske Samlaget.

Popper, K. (1963) Conjectures and refutations. London: Routledge \& Kegan Paul.

Popper, K. (2002) The Open Society And Its Enemies. London: Taylor \& Francis Ltd.

Rasmussen, D. M. (1990) Reading Habermas. Cambridge: Basil Blackwell Inc.

Reinert, E. S. (2009) Spontant kaos. Oslo: Forlaget Res Publica.

Ringstad, V. (2004) Samfunnsøkonomi og økonomisk politikk. Oslo: J. W. Cappelens Forlag.

Robinson, J. (1974) Økonomisk filosofi. Oslo: Gyldendal Norsk Forlag.

Rodrik, D. (2008) One economics, many recipes: Globalization, institutions, and economic Growth. Princeton: Princeton University Press.

Rodrik, D. (2009) Økonomene har skylden. Lastet ned 20. mars 2008 fra www.aftenposten.no/meninger/kommentarer/article2 988 914.ece

Samuelson, P. A. \& Nordhaus, W. D. (2001) Economics. New York: McGraw-Hill.

Schultz, C. (2005) Økonomisk teori - et maktverktøy? RØST 2005-01: Økonomisk teori og politisk praksis. Oslo: Radikalt økonominettverk.

Schumpeter, J. (1994) Capitalism, socialism, and democracy. London: Routledge.

Sejersted, F. (1981) Historisk introduksjon til økonomien. Oslo: J. W. Cappelens Forlag.

Silberberg, E. \& Suen, W. (2001) The structure of economics. New York: McGrawHill.

Sjølie, Ø. (2008) Økonomen er din beste venn. Lastet ned 11. april 2008 fra http:// e24.no/kommentar/e24-kommentar/article2 362 179.ece?service=print 
Skarstein, R. (1976) Sosialøkonomiens elendighet. Oslo: Pax Forlag.

Skarstein, R. (2007) Økonomi på en annen måte. Oslo: Abstrakt Forlag.

Soros, G. (2003) The alchemy of finance. New Jersey: John Wiley \& Sons.

Steigum, E. (2007) Moderne makroøkonomi. Oslo: Gyldendal Norsk Forlag.

Stiglitz, J. (2002) Globalisering: En stor dessillusjon. Oslo: Spektrum Forlag

Stiglitz, J. (2008) Globalisering som virker. Oslo: Pax Forlag

Toulmin, S. (1974) The uses of argument. London: Cambridge University Press.

The Economist (2009, 18. juli) What went wrong with economics.

Tranøy, B. S. (2007) Markedets makt over sinnene. Oslo: Aschehoug Forlag.

Turner, P. T. \& Roth, P. A. (2003) The Blackwell guide to the social sciences. Malden:

Blackwell Publishing Ltd.

Wright, G. H. von (1991) Vitenskapen og fornuften. Oslo: J. W. Cappelens Forlag.

Wyller, T. (1997) Etikkens historie. Oslo: J. W. Cappelens Forlag. 